\title{
How 'Democratic' is the Democratic Peace? A Survey Experiment of Foreign Policy Preferences in Brazil and China*
}

\author{
Clara H. Suong1 \\ https://orcid.org/0000-0002-0558-5111 \\ Scott Desposato ${ }^{2}$ \\ https://orcid.org/0000-0001-7722-1766 \\ Erik Gartzke ${ }^{2}$ \\ https://orcid.org/0000-0001-9439-1310
}

1Duke University, North Carolina, United States

2University of California, California, United States

Recent research has shown that British and American respondents are less willing to advocate the use of force against fellow democracies than against non-democracies (TOMZ and WEEKS, 2013). These findings may contribute to understandings of the 'democratic bias'-unwillingness to attack democracies. A critical next step is assessing whether publics beyond the US and the UK have similar attitudes. To address the scope of popular preferences for peace with democracies, we conduct survey experiments using online panels in two emerging powers, one a democracy (Brazil) and one a non-democracy (China). Our survey randomly varies the hypothetical target's regime type and authorization by the United Nations for military action. We find that Brazilian respondents are significantly less likely to support the use of force against a democracy than a non-democracy. However, after controlling for UN approval, Chinese respondents do not appear to distinguish between democracies and non-democracies when considering whether force is justified. In addition, for both countries, UN approval has a larger effect than democracy on public support for the use of force.

Keywords: Public opinion; Brazil; China; foreign policy; survey experiment.

http://doi.org/10.1590/1981-3821202000010002

For data replication, see https://doi.org/10.7910/DVN/PNDP4V

Correspondence: Clara H. Suong. E-mail: clara.suong@duke.edu

This publication is registered under a CC-BY Licence.

*The authors thank Michael Tessler, Mike Thies, Dustin Tingley, and participants at the Research Seminar at the University College London, the PDEL conference in Park City, Utah, the Experiments in International Relations Conference at Princeton University, the Annual California Graduate Student Conference at UC Irvine, the European Consortium for Political Research's Research Session on Survey Experiments in International Relations at the University of Essex, and the Operant Research Group meeting at UC San Diego's Department of Psychology, and the SCPI conference at UC Santa Barbara for helpful comments. We are indebted to many sources of inspiration and assistance. In particular, funding was provided by the UCSD Committee on Research, the Center for Emerging and Pacific Economies, the UCSD Academic Senate Committee on Research Grants, and the Minerva Initiative, Office of Secretary of Defense \& the Army Research Office, Grant № W911NF-12-1-0355. We thank Bruno Hoepers, Jason Kuo, and Jack Zhang for excellent research assistance. The study was approved by the UCSD Human Research Protections Program, \#121619S. The views and conclusions of this paper are those of the author only and should not be interpreted as representing sponsor or federal government policies or endorsements. Clara H. Suong was partially supported by the National Science Foundation (award number 1637108). 
tudents of politics have devoted enormous attention to exploring the

role that domestic publics play in formulating foreign policy. Evidence of the impact of public opinion has been difficult to unearth, however. Given difficulties with inference and identification, researchers have begun to apply experimental techniques to assist in better understanding relationships.

In a recent example, Tomz and Weeks (2013) demonstrate experimentally that subjects in the United States and the United Kingdom are less willing to advocate attacks against democracies than against non-democratic countries. Popular preferences might thus account for the democratic peace - the observation that democracies seldom fight each other.

Yet while experiments can establish strong causal linkages, ambiguity persists in the interpretation of results and in connecting individual-level findings to macro-level processes. It is not clear, for example, that asking citizens in a democracy whether they are willing to go to war with another democratic country necessarily implies that respondents in a non-democracy will behave differently, or that the populations in all democracies are equally reticent to make war on other democracies. Much remains before researchers can confidently tie findings about a subject's stated preferences to patterns of conflict involving liberal republics. A critical step, as Tomz and Weeks (2013) point out, is to determine the generalizability of the linkage between public opinion, regime type, and war.

How 'democratic' are popular preferences for peace with liberal states? To answer this question, we conducted survey experiments involving subjects in two emerging powers, China and Brazil. The United States and the United Kingdom are 'exceptional' nations, possessing extraordinary wealth, power, social status and with closely linked histories and cultures. The foreign policy attitudes of citizens in these two English-speaking democracies might prove equally exceptional.

The two countries in our survey were chosen with considerable care. Each nation is a rising regional power, capable of acting aggressively if it so chooses. Using military force is thus more than a mere abstraction for publics in either country. Each nation's interests are also at odds with the global status quo; questions about the use of force are unlikely to be confused in the public mind with hegemonic leadership or acting 'as the world's policeman'. 
Brazil is a young democracy, exhibiting key differences from established leading nations. As in many younger democracies, support for democracy is not strong as in the United States or Western Europe; in some surveys, fewer than half of respondents identify democracy as the best form of government. Popular enthusiasm for cooperating with other democracies may be affected by the degree to which democracy is consolidated domestically.

China is a non-democracy. The democratic peace is defined by critical differences in the foreign policy behaviors of democratic and non-democratic states. It is thus essential to examine the determinants of foreign policy in both types of regimes. If public opinion has an impact on the use of force by regimes, then we must examine opinion in both types of systems. Of course, it may well be that public preferences have less impact on foreign policy in authoritarian than in non-authoritarian countries. But this would imply an interaction between institutions and public opinion as the causal mechanism that explains the democratic peace. Either way, a critical first step is empirical - examining public attitudes toward democracies in both democratic and non-democratic regimes. These cases thus offer important variation in regime type, development, status and culture needed to evaluate the generality of the link between public opinion and democratic peace.

A second concern has to do with meaning. Publics may imbue the word 'democracy' with content that researchers ignore at their peril. It is possible that subjects interpret democracy, not as a set of political institutions and norms as understood by academic researchers, but as coded language for a 'good', 'friendly' or 'responsible' country. To find out, we included a second experimental variable in our survey. Subjects were randomly informed that the United Nations had, or had not, authorized using force against a target nation. While only an initial step in determining how subjects perceive democracy, the treatment addresses concerns that democracy may be interpreted by subjects as an authoritative cue indicating quality or virtue.

As it turns out, the public preference for peace with democracies is widespread but context dependent. Respondents from both Brazil and China were generally less likely to endorse military violence against a state when it was randomly identified as a democracy in our experiment. At the same time, however, 
United Nations authorization — or a lack thereof — proved much more important in predicting public preferences for using force.

After reviewing relevant literatures, we detail the benefits of a broader assessment of the connection between public opinion and the democratic peace, across cultures, regime type and economic development. We then discuss details of our experimental design and present the results from the Brazilian and Chinese samples. We conclude by reviewing implications of our findings for democratic peace theory.

\section{Literature: democracy and peace}

Democracies are much more peaceful with each other than are other pairings of states, though democracies are about as war prone as other regimes in general (RUSSETT and ONEAL, 2001) ${ }^{1}$. This implies that democratic dyads are the most cooperative, followed by non-democratic dyads, while mixed dyads (democracy and non-democracy) are the most conflictual. Numerous studies observe or document a significant reduction in conflict in democratic dyads (e.g. BABST, 1964; DOYLE, 1997; HUTH and ALLEE, 2003; LEVY, 1988; MAOZ and RUSSETT, 1993; RUSSETT, 1993; SMALL and SINGER, 1976)².

Theorizing the democratic peace has proven to be a greater challenge. Initial explanations focused on linkages between domestic political attributes and observed reductions in the use of force. Institutionalists argued that representation, deliberation, and civilian bureaucracy inhibit military violence (MESQUITA and LALMAN, 1992; MAOZ and RUSSETT, 1993; RUSSETT, 1993). Kant (1972) saw constitutional constraints as restraining the sovereign's innate proclivity to make war. Normative explanations assign an analogous role to democratic culture (DIXON, 1994; MINTZ and GEVA, 1993; OWEN, 1997; RUSSETT, 1993)33. Constructivists claim that force in the international system is becoming socially

\footnotetext{
1Some debate over whether democracies are generally less warlike, though even advocates admit that this is a weaker relationship (e.g. ROUSSEAU et al., 1996).

${ }^{2}$ Critics of the democratic peace challenge its statistical validity (SPIRO, 1994), or generalizability (HENDERSON, 2002). Others offer alternatives, including alliances (GOWA, 1995), the Cold War (GOWA, 1999), or satisfaction (LEMKE and REED, 1996).

${ }^{3}$ Old democratic dyads appear as dispute prone as new dyads (WARD and GLEDITSCH, 1998).
} 
unacceptable (RISSE-KAPPEN, 1997; WENDT, 1999). Some see the evolution of a common community or identity (DEUTSCH, 1978; FLYNN and FARRELL, 1999). Others assert that mature democracies fail to fight states they perceive as democratic (WEART, 1998)4. Many authors have focused on the informational aspect of democracies, viewing them as more transparent (e.g. SMALL, 1996; VAN BELLE, 1997) or possibly more credible due to the 'audience costs' or opposition groups that enable democracies to signal resolve (e.g. FEARON, 1994; SCHULTZ, 1998, 1999; SMITH, 1998)5.

However, constraint theories have been criticized as ad hoc and deductively flawed (MESQUITA et al., 1999; ROSATO, 2003). Moreover, scholars have noted that efforts to avoid circularity between theory and evidence would benefit most from new empirical content (HUTH and ALLEE, 2003). Work by Mousseau (2000) and Hegre (2000), for example, limits the democratic peace to advanced industrial economies. It is not obvious why norms, institutions, or other factors would inhibit conflict among rich democracies but fail to do so for poor democratic states.

Recent efforts seek to apply public opinion research to the democratic peace, attributing the democratic peace to publics' preferences (e.g. DAFOE et al., 2015; LACINA and LEE, 2013) ${ }^{6}$. For instance, Tomz and Weeks (2013) report a survey experiment of public attitudes toward military violence among US and British citizens. Subjects were asked to consider whether or not their country should use force in a hypothetical international crisis. The study finds a consistent treatment effect for democracy; subjects are significantly less likely to support attacks against a democracy. In a follow-up study, Tomz and Weeks (2018) find that normative concerns separable from democracy matter much more than regime type in explaining popular opinion concerning the use of force. Their survey experiment, again using samples from the United States and the United Kingdom,

\footnotetext{
${ }^{4}$ Liberal leaders or voters may potentially downplay the 'democraticness' of enemy regimes in order to allow themselves to pursue Realpolitik with fewer normative concerns (OREN, 1995).

${ }^{5} \mathrm{C}$.f. Scholars have noted that the original audience cost theory is "silent on whether democracies are more or less able to commit credibly during a crisis" (SLANTCHEV, 2012, p. 378).

${ }^{6}$ See Hyde (2015) for a review of experimental works on International Relations, including those on audience costs.
} 
shows that the pacifying effect of a treatment for whether the target country supports human rights subsumes the effect of the treatment for democracy.

Evidence that citizens care more about whether a hypothetical target is humanistic than democratic suggests a role for social affinity. Common preferences or values may be a key contributor to democratic peace (GARTZKE, 1998, 2000; HUTH and ALLE, 2003). The term 'democracy' may also have important socially constructed connotations for respondents, reflecting subjective normative 'goods' in addition to a nation's actual political attributes.

The notion that democratic peace can be explained by elite or popular affinities is also attractive because it is uncomplicated (FARBER and GOWA, 1997). If democratic citizens or their leaders 'like' each other, then this could account for the democratic peace observation, without requiring an elaborate theory to generate the special dyadic nature of the relationship. However, the risk in such an explanation is that it again tends toward tautology, given that the absence of war among societies is an important indication of affinity. The proper way forward, then, is to assess cases where affinities are not inherent or obvious. If the democratic peace works by making democracies more friendly toward one another, then capable revisionist democracies (such as Brazil) confronting a world dominated by capable democratic powers should behave differently from capable revisionist autocracies (such as China) confronting this same world of powerful status quo democracies.

\section{Theory: public opinion and the democratic peace}

The democratic peace is an observation about how pairs of democracies differ in their foreign policies from other combinations of states. It follows that explaining the democratic peace most likely involves identifying differences between democracies and non-democracies. If public opinion differs systematically between citizens in democracies and non-democracies, then this would be evidence that public attitudes may be critical to the democratic peace.

More generally, while 'micro' evidence of a link between public opinion and a preference for peace toward democracies - at least in some countries - is provocative and interesting, questions remain about how to tie this finding to the 
'macro' evidence typically associated with the dyadic democratic peace observation. The democratic peace is a global phenomenon best suited to evidence that the impact of public opinion on foreign policy spans many, if not most, democracies. While Tomz and Weeks (2013) argue that their results are generalizable "to countries with varying attitudes about military action" (TOMZ and WEEKS, 2013, p. 860), it is difficult to conclude this from their sample. The United States and the United Kingdom are consolidated, wealthy democracies that enjoy a privileged status and whose citizens are somewhat used to interventions abroad. Few countries are more alike, and at the same time are less like other nations in so many respects. The bulk of democracies are younger, poorer, and possess histories of political instability. Many are also confronted by ongoing border disputes, resource crises, and important gaps in human and national security. Given prima facie claims of Anglo exceptionalism (c.f., LIPSET, 1996), an important next step is testing whether Tomz and Weeks's 2013 results hold in more typical democracies.

Further, explaining the relationship between public opinion and the democratic peace also requires diverse regime types. The democratic peace is defined by behavioral differences between democratic and non-democratic regimes. Thus, some consideration of public opinion in non-democracies is warranted. If public opinion alone explains the democratic peace, then democratic publics must typically prefer peace with other democracies, while non-democratic publics should not prefer peace with democracies.

Of course, it may be that institutions matter as well - publics in nondemocracies may have less influence over foreign policy than do democratic publics. However, such a finding would shift scholarly focus from public opinion to the role of democratic institutions. Indeed, it may be that all types of publics generally oppose attacking democracies, but autocratic elites may ignore their constituents, while democratic leaders are forced to listen to popular preferences. This framework could also account for the democratic peace. However, the critical causal variable in this framework would be the way that regimes differ in their attentiveness to public opinion. Public opinion would then be no more causal as a variable - since it would not vary - than the venerable realist concept of international anarchy. Instead, public opinion favorable to democracies would 
merely be a 'permissive condition'. Again, a critical first step is empirical: measuring public attitudes in both democracies and non-democracies.

Our analysis also explores the role of international institutions in opinion formation. Specifically, our survey experiment varies whether or not the proposed use of force has been endorsed by the United Nations. The inclusion of this second treatment helps separate procedural democracy from 'good' countries. Although academics have learned to use terms like 'democracy' with considerable analytical precision, it does not follow that our subjects have in mind the Freedom House definition. Democracy may simply serve as a convenient proxy for things respondents deem to be good or similar to themselves or their nation. Subjects may treat the researcher's use of the term as an authoritative cue that force is unwarranted, and that recommending military action will be frowned upon. Subjects may also view the approval of international institutions as an important mechanism for assessing the legitimacy of proposed uses of force, as suggested by sources in the literature.

Just as 'princely virtues' were once presented as the standard by which the behavior of political leaders was to be evaluated-even though very few princes actually exhibited these virtues - so too 'democracy' has now come to represent a broad and amorphous set of desirable national qualities. Almost every country claims to be a democracy, even those that clearly do not qualify by any reasonable definition. At the same time, enemies are capable of misrepresenting regime type. Saddam Hussein and Fidel Castro each claimed that their regimes were democratic, and each offered a skeptical view of democracy in the United States. Symbolic or socially constructed interpretations of democracy are bound to appear among subjects from powerful western nations, where a country's virtues will tend to be associated with a willingness to accept the status quo. Rather than capturing the effects of the political institutions of democracy on the willingness of subjects to advocate war, experimental research may really be measuring whether the hypothetical opponent is perceived to be in good standing with the international order or is even hostile or friendly. 
A partial solution may stem from evidence that international institutions help to shape public preferences involving the use of force ${ }^{7}$. Experimental work on the effects of IOs (international organizations) on public opinion (TINGLEY and TOMZ, 2012) has shown that the United Nations Security Council's (UNSC) approval boosts public support for war via a process of 'legalizing' the proposed action by granting it moral authority, serving as a useful heuristic for the public. While the regime type of the target country may be perceived as 'cheap talk' on the part of strategic actors, approval from IOs may serve as a more reliable and costly cue from an authoritative entity for determining individuals' stances on the use of force. Existing literature has documented the 'second opinion role' of IOs (GRIECO et al., 2011); it shows that the American public is affected by IO approval of the use of force because it provides a credible cue that such use of force is good policy (CHAPMAN, 2011; GRIECO et al., 2011).

We use international institutional approval of the use of force to control for the virtues of a potential target. Specifically, we vary whether or not the use of force has been approved by the United Nations. We thus measure the impact of regime type on public attitudes in an environment where the international community has judged action necessary, and in one where it has not.

Previous attempts to tie public opinion to the democratic peace have not considered that this relationship may be mediated through international institutions, or that 'democracy' itself may be interpreted by subjects as an authoritative cue to the effect that they should oppose the exercise of military violence. Combined with the exceptional nature of the samples used in previous studies, the danger is that the impact of popular preferences is either too ubiquitous or too unusual to conform to the dyadic macro observation that democracies do not fight each other, while other combinations of regimes continue to interact through force. We explore these possibilities by means of the survey experiment that we detail below.

\footnotetext{
${ }^{7} \mathrm{An}$ international resolution also serves as a commitment mechanism, encouraging domestic publics to 'rally round the flag' and may even lead foreign publics to advocate caution from their own governments (THOMPSON, 2006). International institutional approval further implies greater support and lower costs for states or coalitions authorized to use force, making contests less objectionable to domestic publics.
} 


\section{Experimental design}

The ideal experiment on public opinion and the democratic peace would measure the support of subjects for their government's use of force against every country. An opponent's regime type would be randomly assigned, and each country would face identical scenarios and geopolitical contexts. Our resources are too limited to survey every country, and each country faces unique security environments that no doubt affect public perspectives (compare, for example, Iceland and Israel). However, we believe that careful case selection and an experimental design that decontextualizes security threats helps to advance the literature.

Our study involved survey experiments in China and Brazil. As with previous work (LACINA and LEE, 2013; TOMZ and WEEKS, 2013), we use internetbased polling. Subjects in each country were asked to read short scenarios ('vignettes') about crises involving two hypothetical countries ('A' and 'B') and to express their support for using force. Two treatments were randomly assigned: the regime type of Country B and UN authorization for Country A's use of force.

Our survey used the following format. The script was translated into the local language ${ }^{8}$. Prior to reading the script, subjects were advised that the scenario is hypothetical and should not be read as if it referred to any particular country ${ }^{9}$ : a country in the same part of the world as 'Country A' is developing nuclear weapons and will have its first nuclear bomb within six months. This country (Country B) could then threaten other countries in the region with possible nuclear attack. 'Country A' has attempted to resolve the situation peacefully, but 'Country B' refuses to stop or even discuss the issue. Additional information: 'Country A' would almost certainly defeat 'Country B' in a military dispute. If 'Country B' acquires nuclear weapons, it will have the power to blackmail or destroy other countries. 'Country B' is [not] a democracy. If 'Country A' attacks, it will be able to

\footnotetext{
${ }^{8}$ To assess quality/consistency, different translators re-translated each translation back into English. See Harvard Dataverse for the questionnaires in Portuguese and in simplified and Traditional Chinese. Note that our Chinese respondents had the option to view the survey in either version: https://doi.org/10.7910/DVN/TITSCV

${ }^{9}$ The treatments are in italic. The vignette includes explicit reference to Country A's military dominance over 'Country B' to control for respondents' perception about the likelihood of Country A's victory (GELPI, FEAVER and REIFLER, 2006).
} 
destroy 'Country B's' nuclear development sites and prevent 'Country B' from developing nuclear weapons. The United Nations has [not] authorized 'Country A' to use force against 'Country B' to resolve the situation.

Immediately after the vignette, subjects were asked: should 'Country A' attack and use force to resolve the situation? Subjects were given only two options, attack or not attack.

The first treatment involves a simple dichotomous assignment of the regime type of the nominal target of potential military action: democratic or not democratic. This treatment consists of a one-word change in the vignette, identifying the target country as a democratic neighbor of the potential initiating state, or as a non-democratic neighbor. Explaining the observation of the democratic peace with public opinion requires that democratic publics are not generally less willing to use force - only uniquely more peaceful toward other democracies.

The second treatment varies UN authorization for Country A's use of force against 'Country B'. Extensive theoretical research identifies the approval of international institutions as a key factor in determining popular support for war. One strain of thought emphasizes the legitimizing effect of authorization by an international institution (FINNEMORE, 2003; HURD, 2007). A second perspective argues that international approval plays an informational role, reducing uncertainty about the likely reaction of the international community to a state's use of force (BOEHMER et al. 2004; CHAPMAN, 2011; FANG, 2008; GRIECO et al., 2011; VOETEN, 2005). The combination of regime type and international institutional support for using force defines $2 \times 2=4$ treatments.

The impact of democracy in encouraging peace could be attributed to domestic and/or international institutions. Democracies may be perceived to be more peaceful because of the mechanisms, such as elections, legislatures and courts, that allow popular influence over foreign policy. International institutions could also precipitate peace through their authority or legitimacy, or because subjects perceive approval as indicating something about the target state in the vignette. Including an experimental control for international approval will thus aid in assessing the effect of regime type on popular preferences. While we are not directly concerned here with unraveling the causal mechanisms linking UN approval with 
public opinion, we include questions in the survey about whether respondents care whether their country cooperates with the United Nations, whether their country cooperates with other countries in the region, and whether they believe their government should be more or less active in world affairs.

For consistency with previous work, our vignette discusses a crisis involving a hypothetical neighboring country's pursuit of nuclear weapons (TOMZ and WEEKS, 2013). Research is divided on the impact of nuclear proliferation on interstate conflict (c.f., KROENIG, 2013; SAGAN and WALTZ, 2012; SECHSER and FUHRMANN, 2013). Nevertheless, most people seem to think that nuclear weapons are dangerous, particularly in instances where an adversary is allowed to acquire nuclear capabilities. Our vignette about possible nuclear proliferation in a neighboring state with generally hostile relations should thus tap into popular attitudes about the dangers of proliferation and capture variation in support for the use of military force attributable to democracy.

We intentionally use hypothetical labels for the two states in our vignettes, referring only to 'Country A' and 'Country B'. Previous work has focused on whether a respondent's own country should use force. While not unreasonable, vignettes with descriptive and/or contextual labels pose confounding problems. Consider the potential confounders of asking Brazilian subjects whether a neighbor should be prevented from proliferating. Most will have some difficulty imagining a grave threat emanating from Paraguay (at least since the War of the Triple Alliance). A few may recall that Argentina had a nuclear weapons program in the 1980s. Further, today, every one of Brazil's immediate neighbors is a democracy ${ }^{10}$. What country will they think of if asked to consider using force against a neighboring nondemocracy? The closest nondemocracy is Cuba, with whom Brazil has generally friendly relations. In contrast, China has democratic and non-democratic neighbors, some of whom are already nuclear powers. A Chinese respondent might think of North Korean proliferation, Japanese latent nuclear capabilities, concerns about South Korea and Taiwan, as well as neighbors like Mongolia or Bhutan on one hand and India and Pakistan on the other. Contextual

10Venezuela may be sliding into authoritarianism. 
factors could confound results and make cross-national comparisons difficult. It is difficult to imagine that we could learn anything generalizable about the democratic peace by comparing Brazilians' thoughts on attacking Cuba with Chinese attitudes toward Japan.

Democratic peace theory is supposed to be context free. Countries in the theory have regime type labels but proper nouns are absent. A faithful test of democratic peace theory thus involves questions about hypothetical democracies or non-democracies, not about particular countries in specific contexts. We create a much more general framework for assessing the willingness to use force - one that more nearly reflects the axiomatic nature of democratic peace theory - by using generic country names in our vignettes. Our approach is also useful in simplifying the process of conducting surveys in locations where government officials might reject more specific or pointed survey questions addressing national policy.

The choice to use generic country names also has a more practical motive. Survey firms in China are hesitant to ask any direct questions about Chinese national security policy, and such questions are illegal under Chinese rules on research (LÜ, 2016).

Our design allows us to test the generalizability of Tomz and Weeks' (2013) key findings. Rather than trying to measure public opinion experimentally in all countries, or even selecting a representative sample of states, we focus on a pair of 'critical case' countries, where popular preferences are most likely to delineate the scope of previous findings and connect micro level opinion data to the macro democratic peace observation. As emerging, non-Western powers, Brazil and China also offer a geo-strategic justification for their selection. Each is a member of the 'BRICs', with rising status in the global system, even as each represents an important challenger and focus for opposition to the international status quo. At the same time, Brazil and China provide key variance in terms of regime type. Of course, an important limitation of this design is that we are only examining two countries, and any country-specific idiosyncrasies could confound our findings, so that we cannot generalize to all developing democracies or all developing autocracies. We will test for security context heterogeneity in treatment effects and will also address the limitations of our findings in the discussion. 


\section{Sample}

Our initial survey experiment was conducted online in August and September of $2013^{11}$. We collected a total of 4,214 responses from Brazil and 5,744 responses from China. We conducted a follow-up study in China using a more representative sample recruited by YouGov, where we collected 2,500 responses in April 2015. Survey responses were recorded in an online anonymous survey, with subjects recruited by professional polling companies in each country. Subjects were provided with an online link to the survey experiment, which was programmed in the local language, and routed back to the survey firm's website where subjects were compensated for participating in the survey. We adopted many of Peifer and Garrett's (2014) recommended best-practices for online panels, and data were screened for duplicate responses. Following Tomz and Weeks (2013), we also collected subjects' demographic information - age, gender, education, income, religiosity, and interest in international news - and foreign policy attitudes, such as militarism, internationalism, and nationalism.

While each sample of respondents is not perfectly representative of the population of the two countries, they give us a good picture of the opinions of middle class, well-educated citizens, a sample population that is particularly well disposed to reflect the values sought in democratic peace research. Table 01 reports some descriptive statistics of the respondents12. Chinese respondents were more militaristic and nationalistic than Brazilians, but they were also more internationalist on our composite scale. As expected, Brazilian respondents were more religious than Chinese respondents. In other respects, however, the Brazilian sample was comparable demographically to the Chinese sample. In general, both groups were young, well-educated, economically stable, and distinctly interested in international affairs.

\footnotetext{
${ }^{11}$ The data and the code to reproduce results will be available on all authors' websites after publication, as well as in Harvard Dataverse (DOI: https://doi.org/10.7910/DVN/PNDP4V).

${ }^{12}$ Attitudinal measures - militarism, internationalism, nationalism, religiosity - are scaled on a 0 1 interval. For the Brazilian sample, Cronbach's alpha for the militarism index was 0.28 , 0.65 for internationalism, and 0.61 for nationalism. For the China sample, Cronbach's alpha was 0.49 for militarism, 0.42 for internationalism, and for 0.41 nationalism. Please see the Appendix for additional information on each sample (Table S05, Table S06, Table S07, Table S08).
} 
How might these sampling frames affect results? Without observing a fully representative sample, we cannot be sure, but we did examine the World Values Survey from Wave 06 (INGLEHART et al., 2014) for some indications. For both Brazil and China, we examined the relationship between internet access, education, and respondent ratings of the importance of democracy. For both countries, daily internet access increases the percentage of respondents that say democracy is, 'absolutely important' by about 10 percentage points (Brazil, no access to internet, $44 \%$ versus daily access 55\%; China no access $26 \%$, daily access $36 \%$ ). Similarly, comparing attitudes about democracy as a function of education, the percentage responding that democracy is 'absolutely important' increases with education, but similarly in both countries. Respondents with a primary school education who called democracy, 'absolutely important' were $40 \%$ of respondents in Brazil and 28\% of respondents in China; for those with a secondary education the percentages were $49 \%$ and $35 \%$.

Table 01. Descriptive statistics of the samples

\begin{tabular}{llll} 
& Brazil & China & \\
\cline { 2 - 4 } & & Sample 01 & Sample 02 \\
\hline Mean & & & \\
$\quad$ Militarism (0-1) & 0.258 & 0.510 & 0.460 \\
Internationalism (0-1) & 0.599 & 0.718 & 0.698 \\
$\quad$ Nationalism (0-1) & 0.410 & 0.744 & 0.734 \\
$\quad$ Religiosity (0-1) & 0.338 & 0.098 & 0.087 \\
$\quad$ Age & 36.112 & 31.375 & 32.288 \\
Read International News (Days & 4.059 & 4.551 & 3.472 \\
Per Week) & & & \\
\hline Median & Some College & College Degree & College Degree \\
Education & & & \\
\hline Income Quintile & 4 th & 4 th & \\
Percentage & & & 57.640 \\
Male & 48.090 & 56.513 & 44.837 \\
Religious & 85.587 & 43.318 & 2,500 \\
Overall N & 4,214 & 5,744 & \\
\hline
\end{tabular}

Source: Prepared by the authors with their own data.

Note: There is no significant difference at the 0.05 level on any demographic covariates across treatments, barring the Brazil sample's religiosity. The p-value for the ANOVA of the Brazilian sample's religiosity on treatment was 0.0496 , close to being insignificant at the 0.05 level.

Consequently, excluding those with no internet access or with the lowest educational levels will probably inflate the impact of democracy, and given the similar relationships between internet access and democracy observed in the World Values Survey (INGLEHART et al., 2014), this effect will likely be similar in 
each country. Note that the same pattern is even stronger in the United States, where previous work on this topic has used internet-based surveys (no internet access, democracy 'absolutely important', 37\%, daily internet access, 52\%). For our study, this means we can still explore whether patterns in Brazil and China are different than or the same as those documented in the United States, but we cannot claim that our results are representative of all Brazilians or all Chinese. We partially addressed this with our second sample where we oversampled low education respondents.

In an ideal world, we would have a fully representative sample for both of our cases. Tomz and Weeks (2013) do not provide this, even using samples from the United States and the United Kingdom. A representative sample in an internet survey in China, and to a lesser extent, Brazil would be quite difficult - perhaps impossible - to obtain. In practice, our sample is heavily weighted towards elites, especially in China. This has some benefits. Urban elites are most likely to have opinions on foreign policy. Elites are also the most likely group to influence foreign policy, especially in an authoritarian regime, where social networking sites, online discussions, and calls for collective action are closely monitored.

\section{Results}

The sections below review the major findings for our study. The results reveal surprising differences and remarkable similarities across two populations with very different cultures and political structures. A final section attempts to make sense of these findings.

\section{Main effects of regime type}

Table 02 reports the effect of the target country's regime type on public support for the use of force in Brazil and China. Figures are the percentage of subjects in each country and treatment that answered 'yes', when asked whether 'Country A' should use force against 'Country B'. Citizens of both countries were significantly less likely to support the use of force against a democracy than against a non-democracy. Only 32 percent of Brazilian subjects - less than a third - supported attacking a democracy whereas nearly 40 percent backed military 
action against a non-democratic target. The estimated effect of regime type was thus -7.7 percentage points in Brazil, significant at the 0.05 level. Chinese subjects were uniformly more willing to support the use of force. Over fifty percent of Chinese subjects supported using force against 'Country B' in both treatments. However, there was a significantly smaller effect of democracy. When 'Country B' was democratic, 50 percent of Chinese respondents advocated using force. Support for using force increased only modestly, to approximately 53 percent, when the target was a non-democracy. The effect of regime type is thus about -2.8 percentage points for Sample 01 and the YouGov Sample with the former - but not the latter — significant at the 0.05 level.

These experimentally-generated effects demonstrate consistency with findings offered by Tomz and Weeks (2013). Brazilian subjects are reluctant to advocate war with a democracy. Chinese respondents show the same tendency but are: 01 . more willing to use force; and 02 . less responsive to the democracy treatment.

Table 02. Percentage support for attacking and the effect of democracy

\begin{tabular}{|c|c|c|c|c|c|}
\hline & Brazil & & China & & \\
\hline & $\begin{array}{l}\text { \% Support for } \\
\text { Attacking }\end{array}$ & $\mathrm{N}$ & $\begin{array}{l}\text { Sample } 01 \\
\% \text { Support } \\
\text { for Attacking }\end{array}$ & $\begin{array}{l}\text { Sample } 02 \\
\text { \% Support for } \\
\text { Attacking }\end{array}$ & $\mathrm{N}$ \\
\hline $\begin{array}{l}\text { Democratic } \\
\text { target }\end{array}$ & 32.070 & 2,111 & 50.090 & $\begin{array}{l}2,793 \\
50.977\end{array}$ & 1,228 \\
\hline $\begin{array}{l}\text { Non- } \\
\text { democratic } \\
\text { target }\end{array}$ & 39.838 & 2,101 & 52.847 & $\begin{array}{l}2,950 \\
53.785\end{array}$ & 1,268 \\
\hline $\begin{array}{l}\text { Effect of } \\
\text { democracy } 95 \\
\% \text { C.I. }\end{array}$ & $\begin{array}{l}-7.768 \\
(-10.658 \text { to }- \\
4.877)\end{array}$ & & $\begin{array}{l}-2.758 \\
(-5.344 \text { to }- \\
0.171)\end{array}$ & $\begin{array}{l}-2.808 \\
(-6.729 \text { to } 1.113)\end{array}$ & \\
\hline
\end{tabular}

Source: Prepared by the authors with their own data.

Note: The table shows the percentages of respondents who supported military action against a democratic target and a non-democratic target. The difference in the percentages is considered as the effect of democracy.

Table 03 shows support for the use of force by regime type and by UN approval. The effect of democracy persists after controlling for UN approval for the Brazilian sample but not for the Chinese samples. For Brazil, only 38 percent of respondents supported a UN-approved attack against the democratic nuclear proliferator, while roughly 47 percent endorsed an attack against a non- 
democratic target with UN approval. The impact of democracy for the Brazilian sample treated with UN approval was thus -9 percentage points. The effect of democracy was also significant in the absence of UN approval, but was smaller. Approximately 26 percent of Brazilian respondents supported an attack against a democratic nuclear proliferator without UN authorization whereas about 31 percent backed an attack against a non-democratic target without UN approval. The effect of democracy for the Brazilian sample without UN approval decreased to -5 percentage points, smaller than its equivalent with UN approval but still statistically significant.

For Chinese respondents, the effect of democracy was much smaller and at times insignificant after controlling for UN approval. When force was approved by the United Nations, 54 percent of Chinese respondents in the first sample and 58 percent in the YouGov sample backed an attack against a democracy compared with 56 percent and 58 percent who supported military action against a non-democracy, a difference that is not statistically significant. The effect of democracy was also smaller for Chinese respondents in the 'no UN approval' condition. Approximately 45 percent of those assigned democratic Country B without UN approval in the first study and 44 percentage in the YouGov study favored an attack versus nearly 49 percent in the case of a non-democratic Country B for both samples. The effect of regime type was again insignificant. In each country, the difference was not significant; variation in the size of the democracy effect was not significant.

The table also reveals the effect of UN approval on willingness to advocate force. In both countries, the effect is much larger than for democracy. For Brazilians facing a democratic target, UN approval produces nearly a 12percentage point increase in willingness to use force. The effect is even larger when regarding non-democratic targets (almost 17 percentage points). Both of these effects are statistically significant. For Chinese subjects, the impact of UN approval is close to 8 percentage points - and 14 and 09 percentage points in the YouGov sample - in democratic and non-democratic treatments. 
Table 03. Percentage support for an attack and the effect of democracy, controlling for UN approval

\begin{tabular}{|c|c|c|c|c|c|c|}
\hline & & & $\begin{array}{l}\text { Democratic } \\
\text { target }\end{array}$ & $\begin{array}{l}\text { Non } \\
\text { democratic } \\
\text { target }\end{array}$ & $\begin{array}{l}\text { Effect of } \\
\text { democracy }\end{array}$ & 95\% C. I. \\
\hline \multirow[t]{4}{*}{ Brazil } & & UN Approval & 38.086 & 47.729 & -9.643 & $\begin{array}{l}(-13.839 \text { to }- \\
5.447)\end{array}$ \\
\hline & & $\begin{array}{l}\% \text { Support for } \\
\text { attack N }\end{array}$ & 1045 & 1079 & & \\
\hline & & $\begin{array}{l}\text { No UN } \\
\text { Approval }\end{array}$ & 26.173 & 31.507 & -5.334 & (9.216 to -1.452$)$ \\
\hline & & $\begin{array}{l}\% \text { Support for } \\
\text { attack N }\end{array}$ & 1066 & 1022 & & \\
\hline \multirow[t]{10}{*}{ China } & Sample & UN Approval & 54.435 & 56.868 & -2.433 & $(-6.080$ to 1.214$)$ \\
\hline & 01 & $\begin{array}{l}\text { \% Support for } \\
\text { attack N }\end{array}$ & 1398 & 1456 & & \\
\hline & & No UN & 45.735 & 48.929 & -3.194 & $(-6.838$ to 0.450$)$ \\
\hline & & Approval & & & & \\
\hline & & $\begin{array}{l}\text { \% Support for } \\
\text { attack N }\end{array}$ & 1395 & 1494 & & \\
\hline & Sample & UN Approval & 58.347 & 58.665 & -0.318 & $(-5.799$ to 5.163$)$ \\
\hline & 02 & $\begin{array}{l}\text { \% Support for } \\
\text { attack N }\end{array}$ & 617 & 629 & & \\
\hline & & No UN & 43.535 & 48.983 & -5.448 & $(-10.979$ to \\
\hline & & Approval & & & & $0.083)$ \\
\hline & & $\begin{array}{l}\text { \% Support for } \\
\text { attack N }\end{array}$ & 611 & 639 & & \\
\hline
\end{tabular}

Source: Prepared by the authors with their own data.

Note: The table displays the percentages of respondents who supported military action against a democratic target and a non-democratic target, controlling for UN approval. The difference in the percentages is considered as the effect of democracy.

These results suggest several initial conclusions. First, there is an effect of democracy in Brazil, and evidence of a suggestive but not significant effect in China. Second, in both cases, there is an even larger impact of UN approval on the willingness to use force. Finally, our Chinese subjects are generally more supportive of using force than are our Brazilian subjects. These differences between Brazil and China are striking but may reflect demographic differences or other features of sample variability. For example, China's sample is younger and more male than the Brazilian sample, variables associated with a willingness to advocate force. We next conduct multivariate analysis to address a variety of demographic and attitudinal variables.

\section{Robustness checks}

We complement our basic analysis with robustness checks in the presence of control variables. We adopt two strategies. First, we use logistic regression to 
predict support for 'Country A' using force against 'Country B', controlling for demographic and attitudinal variables. Second, we examine the simple effect of democracy for different values of control variables.

Table 04 reports results from a logistic regression of respondent support for the use of force incorporating both our experimental variables and also attitudinal and demographic controls. The variable labels 'Democracy' and 'UN Approval' denote the experimental treatments. Following existing works on support for the use of force, 'Militarism', 'Internationalism' (HURWITZ and PEFFLEY, 1987; HERRMANN et al., 1999; TOMZ and WEEKS, 2013), and 'Nationalism' (JOHNS and DAVIES, 2012) are composite measures that control for a respondent's basic foreign policy disposition.

The results reiterate the earlier summary tables: regime type and international organization approval affect subjects' attitudes toward the use of force, in both Brazil and China. In both countries, respondents are significantly less willing to approve the use of force against a democracy but are much more willing to support an attack sanctioned by the United Nations. Variables for both treatments are significant at the 0.05 level in both countries. Both sets of coefficients are consistent with our basic results; democracy diminishes support for using force, while support for war increases with UN endorsement.

Many of the demographic variables are statistically significant for Brazil but not for China, though the signs are nearly always the same. For Brazil, demographic factors such as age, gender, education, income, and interest in international news are all significant at the 0.05 level. Older, female, bettereducated Brazilians were more likely to oppose war, while Brazilians with higher incomes and a strong interest in international news were more likely to support war. The lack of significance for most Chinese demographics controls may reflect sampling differences. The Chinese sample is less demographically diverse than the Brazil sample; there is less variance to leverage in estimating these coefficients. Generally, Chinese respondents tend to be younger than Brazilian respondents; the mean age for Chinese respondents is 31 (Sample 01) or 32 (YouGov Sample), with a standard deviation of 8 (Sample 01) or about 11 (YouGov Sample), whereas the mean age for Brazilian subjects is 36 and the standard deviation is 12 . 
Chinese respondents are overall better educated, with 73 percent reporting that they have a college degree whereas only 26 percent of Brazilian respondents claiming this level of formal education. Chinese respondents are also much less religious than Brazilian respondents, 85 percent of whom reported having a religion ${ }^{13}$.

Table 04. Logistic regressions of support for attacks among Brazilian and Chinese subjects

\begin{tabular}{|c|c|c|c|}
\hline \multirow{2}{*}{ Support for Attacks } & \multicolumn{2}{|c|}{ Dependent variable } & \\
\hline & Brazil & China & \\
\hline \multirow{3}{*}{ Democracy } & & Sample 01 & Sample 02 \\
\hline & $0.359 * * *$ & $0.188^{* *}$ & $0.249^{* *}$ \\
\hline & $(0.114)$ & $(0.082)$ & $(0.124)$ \\
\hline \multirow[t]{2}{*}{ UN Approval } & $0.662^{* * *}$ & $0.400^{* * *}$ & $0.509^{* * *}$ \\
\hline & $(0.107)$ & $(0.082)$ & $(0.124)$ \\
\hline \multirow[t]{2}{*}{ Militarism } & $1.627^{* * *}$ & $1.752^{* * *}$ & $1.253^{* * *}$ \\
\hline & $(0.128)$ & $(0.077)$ & $(0.115)$ \\
\hline \multirow[t]{2}{*}{ Internationalism } & $0.803^{* * *}$ & $-0.783^{* * *}$ & -0.483 \\
\hline & $(0.223)$ & $(0.246)$ & $(0.366)$ \\
\hline \multirow[t]{2}{*}{ Nationalism } & $0.471^{* * *}$ & $0.825^{* * *}$ & $0.799 * * *$ \\
\hline & $(0.171)$ & $(0.186)$ & $(0.271)$ \\
\hline \multirow[t]{2}{*}{ Specific Case } & $0.208^{* *}$ & $0.216^{* * *}$ & $0.229 * *$ \\
\hline & $(0.087)$ & $(0.066)$ & $(0.101)$ \\
\hline \multirow[t]{2}{*}{ Age } & $0.013^{* * *}$ & 0.005 & $0.016^{* * *}$ \\
\hline & $(0.003)$ & $(0.004)$ & $(0.004)$ \\
\hline \multirow[t]{2}{*}{ Female } & $0.309^{* * *}$ & -0.018 & -0.082 \\
\hline & $(0.080)$ & $(0.061)$ & $(0.094)$ \\
\hline \multirow[t]{2}{*}{ Education } & $0.081^{* * *}$ & -0.048 & -0.024 \\
\hline & $(0.031)$ & $(0.032)$ & $(0.038)$ \\
\hline \multirow[t]{2}{*}{ Income Quintile } & $0.077^{* *}$ & -0.011 & 0.026 \\
\hline & $(0.038)$ & $(0.031)$ & $(0.044)$ \\
\hline \multirow[t]{2}{*}{ International News } & $0.038^{* *}$ & -0.007 & 0.023 \\
\hline & $(0.016)$ & $(0.014)$ & $(0.019)$ \\
\hline \multirow[t]{2}{*}{ Religion } & 0.189 & -0.041 & 0.072 \\
\hline & $(0.118)$ & $(0.066)$ & $(.096)$ \\
\hline \multirow[t]{2}{*}{ Religiosity } & -0.169 & 0.074 & $0.753^{* * *}$ \\
\hline & $(0.117)$ & $(0.156)$ & $(0.239)$ \\
\hline \multirow[t]{2}{*}{ Democracy X UN Approval } & 0.103 & 0.018 & 0.224 \\
\hline & $(0.154)$ & $(0.117)$ & $(0.177)$ \\
\hline \multirow[t]{2}{*}{ Constant } & $-1.516^{* * *}$ & $-0.898^{* * *}$ & $-1.573^{* * *}$ \\
\hline & $(0.265)$ & $(0.276)$ & $(0.349)$ \\
\hline Observations & 3,282 & 5,431 & 2,303 \\
\hline Akaike Inf. Crit. & $4,015.057$ & $6,811.196$ & $2,955.631$ \\
\hline
\end{tabular}

Source: Prepared by the authors with their own data.

Note: ${ }^{*} \mathrm{p}<0.1 ;{ }^{* *} \mathrm{p}<0.05 ;{ }^{* * *} \mathrm{p}<0.01$.

${ }^{13}$ See Appendix for more information about each sample's summary statistics (Table S06, Table S07, Table S08). 
In both countries, self-reported levels of militarism, internationalism, and nationalism had a sizable effect on the likelihood of a respondent advocating the use of force. Not surprisingly, a respondent with strong militaristic attitudes is more likely to support military action than are less militaristic individuals. Nationalistic respondents in both countries tend to be more favorable toward to the use of force than less nationalistic respondents. Higher levels of these two variables in China may explain the greater overall willingness of Chinese respondents to use force. Those who thought of specific cases in response to the vignettes were also more likely to favor aggressive foreign policy action, which may explain the relatively smaller effect sizes in studies with hypothetical situations than in studies that rely on real cases ${ }^{14}$.

Perhaps the most striking distinction between the two samples occurs in the context of the internationalism measure, which produced large, significant but contrasting effects for Brazil and China. Internationalism substantially increases support for using force among Brazilian subjects of the survey experiment, whereas it is negatively associated with a willingness to war among Chinese subjects. We speculate that this difference reflects contrasts in how subjects in the two countries interpret the role of the United Nations. China's permanent seat on the UN Security Council may alter the meaning of UN authorization for some Chinese, as UN authorization requires, at a minimum, China's acquiescence.

Figure 01 shows the mean predicted probability of an average respondent from each sample supporting the use of force in each country, contingent on the target's regime type and UN approval ${ }^{15}$. Attitudinal variables, such as militarism, internationalism, nationalism, were held at their means and other control variables at their medians of each country.

\footnotetext{
${ }^{14}$ For our large two samples, we checked for heterogenous treatment effects due to compliance by testing our models on those who followed our instructions to think of a generic case and those who admitted to thinking of specific cases. The results were largely similar, and the direction of the treatments' effects were consistent across the four subsamples. Including a model with interaction terms for the two treatments and a variable for specific cases also showed that there were no interaction effects between the two treatments and specific cases at the 0.05 level. The appendix includes Table S09 listing the ten countries most often listed by subjects who admitted they were thinking of a specific country, rather than a generic one as instructed.

${ }^{15}$ Note that scholars have criticized the use of regression and logistic regression to analyze experimental data and proposed adjustments and alternatives for examining predicted values. We separately calculated Freedman's 2008 plug-in estimator and obtained very similar results.
} 
Figure 01. Predicted probabilities of an average respondent supporting the use of force

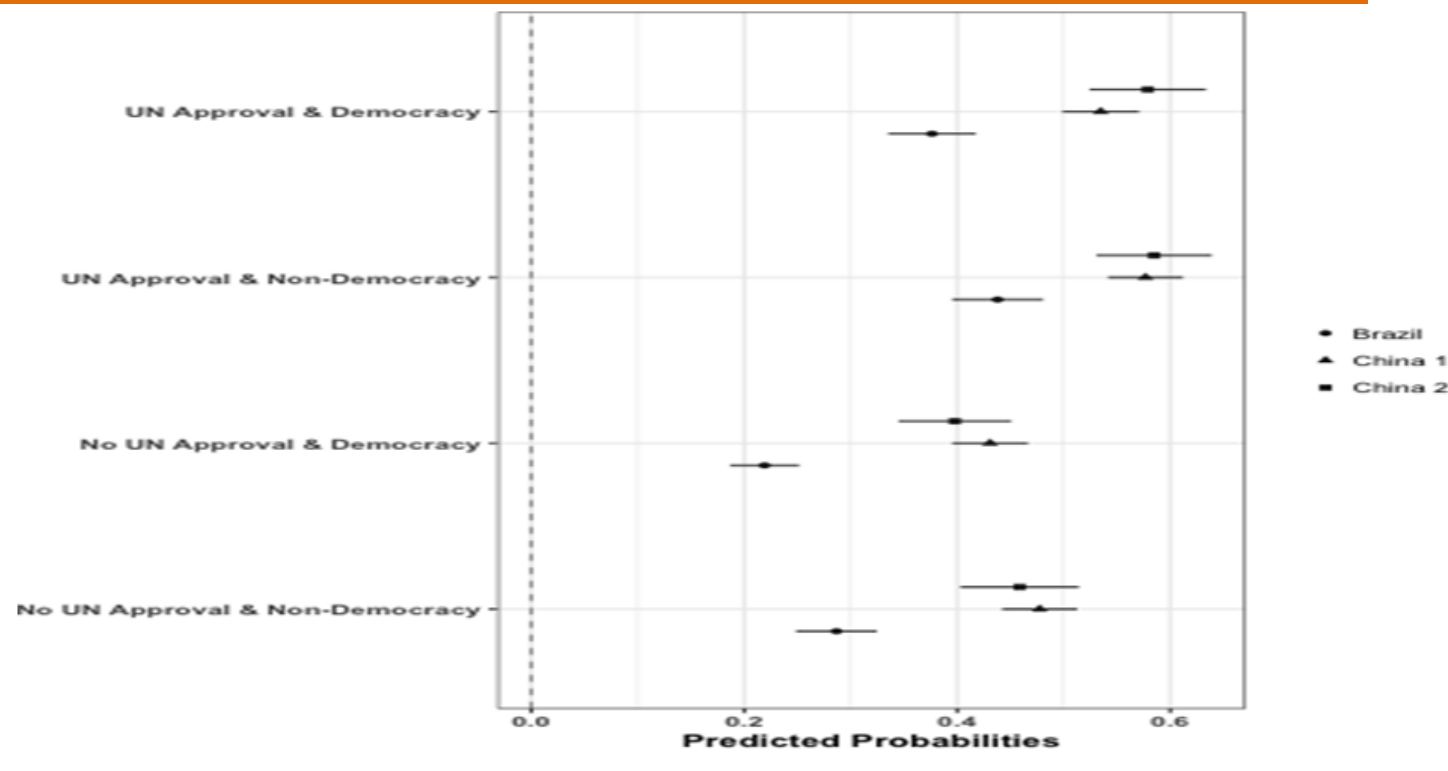

Source: Prepared by the authors with their own data.

The predicted probabilities generated reveal how these citizens react to the target country's regime type and IO endorsement. Again, the rallying effect of UN approval is clear whereas the pacific effect of democracy is weaker. Given UN approval, the predicted probability of the Brazilian respondent advocating the use of force against a non-democratic nuclear proliferator is 0.43 and against a democratic proliferator is 0.37 . Without UN approval, however, the probability of supporting war decreases to 0.28 when the target is a non-democratic regime and further to 0.21 when the target is a democracy. Similarly, the predicted probability that a Chinese subject in our first sample backs military action sanctioned by the $\mathrm{UN}$ is 0.57 against a non-democratic target and 0.53 against a democratic target. Without authorization by the United Nations, the likelihood that Chinese respondents support an attack is 0.47 if the target regime is non-democratic and 0.43 if the target is said to be a democracy. In our follow-up study in China, the predicted probability that a Chinese subject supports an UN approved attack is about 0.58 regardless of the target's regime type. Without UN approval, the predicted probability is 0.45 against a non-democratic target and 0.39 against a democracy. 
Of course, the average respondent does not represent the average citizen. For this reason, we also generated predicted values using population medians and percentages for age group, education and gender (not shown) (Minnesota Population Center, 201716). The comparative patterns were identical as were the hypothesis tests. The only difference was that in every cell the predicted probability of support for using force was about 0.05 higher for the population mean than for the sample mean. This was true for both Brazil and China, reflecting greater support for the use of force among poorer and less educated subjects.

As an alternative robustness check, we examine the effect of the treatment as a function of each of the control variables in our Appendix. The analysis result for Brazil, shows how strong and consistent the effect of democracy is on the expressed support for Country A's use of force. Of the 29 reported treatment effects of regime type, 28 are negative - meaning that democracy reduced support for Country A's use of force. Further, 23 of the 29 are statistically significant, and those that are not tend to have small samples and low power.

The results are weaker for China. Of the 29 estimated effects, 26 are again negative, and the positive values tend to have very small sample sizes - in one case, just 11 subjects ${ }^{17}$ ! On the other hand, only 09 of the 29 are significantly different from zero. This may reflect real variation within the population, or it may just reflect lower power given the slightly smaller effect of democracy in China. Our study does not provide the power needed to explore all these differences, but several are intriguing and worth mentioning. The lowest education cohort actually had a positive treatment effect - they were more likely to support attacking a democratic Country B. The impact of democracy was very large for subjects with low nationalism, but again, the sample size in this category is very small.

We also estimated the treatment effects using randomization inference (RIGDON and HUDGENS, 2015) ${ }^{18}$. The results do not change substantially. Among our Brazilian sample, the average treatment effect (ATE) based on

\footnotetext{
${ }^{16}$ The authors wish to acknowledge the statistical offices that provided the underlying data making this research possible: Institute of Geography and Statistics, Brazil and National Bureau of Statistics, China.

170nly 11 Chinese subjects in Sample 1 scored 'Weak' on the Internationalism index.

${ }^{18}$ The effects were estimated using the R package RI2by2.
} 
attributable effects was estimated as -7.7 percent for our democracy treatment with the confidence interval from -11 to -4.4 percent $^{19}$. Among our Chinese samples, the ATE based on attributable effects was -2.7 percent (Sample 01) and 2.8 percent (YouGov sample) for our democracy treatment. The confidence interval for the effect was from -5.6 to 0.1 percent for the former and from -7.2 to 1.6 percent for the latter ${ }^{20}$.

\section{Discussion}

This study provides evidence of democracy's pacifist but limited effect among respondents from Brazil and China. Respondents from Brazil, a democracy, are less supportive of the use of force against another democracy, but respondents from China, a non-democratic country, do not distinguish between regime type. Apparently, the willingness to fight a democracy is highly context dependent. In addition, our study suggests an existence of a large signaling effect of IO endorsements on public opinion. Respondents were extremely sensitive to the cues from international organizations - more than the cues about the potential target country itself. In other words, respondents from Brazil and China are more supportive of attacking a democracy if an international organization approves the attack.

Our findings show that Tomz and Weeks' (2013) work on the United States and United Kingdom do not neatly generalize to all countries, with important differences in the impact of democracy on the willingness to use force when comparing Brazil and China. One possible interpretation is that our findings provide evidence in support of a democratic peace - respondents in democratic Brazil were less supportive of using force against another democracy than against an autocracy; respondents in authoritarian China made no such distinction. However, a major limitation of the study is that, since we only examined two countries, we cannot say decisively that the differences in treatment effects between China and Brazil are driven only by those countries' regime types

\footnotetext{
${ }^{19}$ The estimated effect for the UN approval treatment was 14.2 percent with the confidence interval from 10.9 to 17.4 percent.

${ }^{20}$ The effect for the UN treatment was estimated as 8.2 percent (Sample 01) and 12.1 percent (YouGov Sample). Their confidence intervals were from 5.3 to 11.2 percent and from 7.7 to 16.5 percent.
} 
or that these findings generalize more broadly to other democracies or authoritarian regimes. Each country is situated in a very different security context which could explain its perspectives on the use of force. We attempted to partially address these challenges by decontextualizing our experimental vignette to use generic situations rather than a threat facing our respondents' own countries. Further, when testing for heterogeneity in treatment effects and when respondents reported thinking of one context or another, we failed to reject the null of no heterogeneity, suggesting that our decontextualized vignette was effective. Even so, there are many other differences between these cases, including economic, historical, and even cultural, that could explain away our results. At the same time, although our ability to generalize is limited, Brazil and China are both leading countries demographically, militarily, and economically, and as such, our finding that support for a democratic peace is stronger in Brazil than in China remains important.

Our study is also limited by our sampling method. Like other scholars working in this area, we rely on an internet-based survey drawn from a commercial panel, not random samples ${ }^{21}$. For the Chinese case, we validated our results with a second survey that over-sampled respondents with low-levels of education. Ultimately, however, scholars studying the public opinion of a nondemocratic country face a conundrum. They can strive to recruit a nationally representative sample characteristic of 'the median voter'. However, it is unclear whether a median voter is a meaningful political entity in a society lacking universal suffrage. An ideal sample of respondents for a non-democracy may consist of elites, individuals who more nearly reflect a 'pivotal' opinion in the society. Researchers may need to make a choice between the median voter sample and the pivotal voter sample, facing questions and concerns in each case about what 'representative' means in a polity that lacks representation. We chose to

\footnotetext{
${ }^{21}$ Public opinion researchers debate the use of non-random samples and survey mode differences. Many are skeptical about opt-in Internet surveys and strongly prefer face-to-face interviews or telephone surveys with randomly selected samples. Some (e.g. MALHOTRA and KROSNICK, 2007) find substantial differences between telephone surveys with random-digit dialing or internet surveys. Others (e.g. ANSOLABEHERE and SCHAFFNER, 2014) find that opt-in web surveys, telephone surveys, and mail surveys with identical questions produce similar results after weighting or matching.
} 
pursue both options, collecting and analyzing data from a more representative sample of the Chinese population through YouGov, in addition to the initial samples. The results from both samples are largely consistent.

These limitations suggest directions for future research. An important next step would be to extend this research to a larger sample of countries, ideally with fully representative simple random samples. In addition, future work should also further dissect and explore the meaning of democracy for research subjects. The limited popularity of democracy in China might well derive from different factors than those that provide its appeal in Brazil or the United States, though we were unable to find any indications of this in the current research design. It remains possible that 'democracy' means different things in different places. Perhaps democratic citizens may correctly perceive democracy while the subjects of nondemocratic regimes may mis-interpret the label. Perhaps, too, 'democracy' means something subjective in both democracies and nondemocracies.

While our discovery of the 'democratic' nature of popular preferences for peace with democracies is important, we find an even larger effect of UN approval on individuals' support for the use of force. Our effort here has focused on the role of democracy and thus we have devoted less attention to the effects of UN approval. Nonetheless, the strong experimental performance of UN authorization and its close relationship to concepts of liberal peace calls for further investigation.

Revised by Fraser Robinson Submitted on November 14, 2018 Accepted on June 04, 2019

\section{References}

ANSOLABEHERE, Stephen and SCHAFFNER, Brian F. (2014), Does survey mode still matter? Findings from a 2010 multi-mode comparison. Political Analysis. Vol. 22, № 03, pp. 285-303.

BABST, Dean V. (1964), Elective governments: a force for peace. The Wisconsin Sociologist. Vol. 03, № 01, pp. 09-14.

BOEHMER, Charles; GARTZKE, Erik, and NORDSTROM, Timothy W. (2004), Do intergovernmental organizations promote peace? World Politics. Vol. 57, № 01, pp. 01-38. 
CHAPMAN, Terrence L. (2011), Security approval: domestic politics and multilateral authorization for war. Chicago: University of Chicago Press. 208 pp..

CHINA INTERNET NETWORK INFORMATION CENTER (2014), Statistical report on internet development in China. Available at <https://cnnic.com.cn/IDR/ReportDownloads/201411/P020141102574314897 888.pdfs. Accessed on June, 25, 2018.

DAFOE, Allan; ZHANG, Baobao, and CAUGHEY, Devin Michael (2015), Confounding in survey experiments. Paper retrieved from osf.io/c5h8q.

DEUTSCH, Karl Wolfgang (1978), The analysis of international relations. Englewood Cliffs: Prentice-Hall. 214 pp..

DIXON, William J. (1994), Democracy and the peaceful settlement of international conflict. American Political Science Review. Vol. 88, № 01, pp. 14-32.

DOYLE, Michael W. (1997), Ways of war and peace: realism, liberalism, and socialism. New York: Norton. 557 pp..

FANG, Songying (2008), The informational role of international institutions and domestic politics. American Journal of Political Science. Vol. 52, № 02, pp. 304321.

FARBER, Henry S. and GOWA, Joanne (1997), Common interests or common polities?: reinterpreting the democratic peace. Journal of Politics. Vol. 59, № 02, pp. 393-417.

FEARON, James D. (1994), Domestic political audiences and the escalation of international disputes. American Political Science Review. Vol. 88, № 03, pp. 577-592.

FINNEMORE, Martha (2003), The purpose of intervention: changing beliefs about the use of force. Ithaca: Cornell University Press. $184 \mathrm{pp}$.

FLYNN, Gregory and FARRELL, Henry (1999), Piecing together the democratic peace: the CSCE, norms, and the 'construction' of security in Post-Cold War Europe. International Organization. Vol. 53, № 03, pp. 505-535.

FREEDMAN, David A. (2008), Randomization does not justify logistic regression. Statistical Science. Vol. 23, № 02, pp. 237-249.

GARTZKE, Erik (2000), Preferences and the democratic peace. International Studies Quarterly. Vol. 44, № 02, pp. 191-212. 
GARTZKE, Erik (1998), Kant we all just get along?: Motive, opportunity, and the origins of the democratic peace. American Journal of Political Science. Vol. 42, № 01 , pp. 01-27.

GELPI, Christopher; FEAVER, Peter D., and REIFLER, Jason (2006), Success matters: casualty sensitivity and the war in Iraq. International Security. Vol. 30, № 03, pp. 07-46.

GOWA, Joanne (1999), Ballots and bullets: the elusive democratic peace. Princeton: Princeton University Press. 144 pp..

GOWA, Joanne (1995), Democratic states and international disputes. International Organization. Vol. 49, № 03, pp. 511-522.

GRIECO, Joseph M.; GELPI, Christopher; REIFLER, Jason, and FEAVER, Peter D. (2011), Let's get a second opinion: international institutions and American public support for war. International Studies Quarterly. Vol. 55, № 02, pp. 563583.

HEGRE, Håvard (2000), Development and the liberal peace: what does it take to be a trading state. Journal of Peace Research. Vol. 37, № 01, pp. 05-30.

HENDERSON, Errol A. (2002), Democracy and war: the end of an illusion. Boulder: Lynne Rienner. 191 pp.

HERRMANN, Richard K.; TETLOCK, Philip E., and VISSER, Penny S. (1999), Mass public decisions to go to war: a cognitive-interactionist framework. American Political Science Review. Vol. 93, № 03, pp. 553-573.

HURD, Ian (2007), After anarchy: legitimacy and power in the United Nations Security Council. Princeton: Princeton University Press. 221 pp..

HURWITZ, Jon and PEFFLEY, Mark (1987), How are foreign policy attitudes structured? A hierarchical model. American Political Science Review. Vol. 81, № 04, pp. 1099-1119.

HUTH, Paul K. and ALLEE, Todd L. (2003), The democratic peace and territorial conflict in the twentieth century. Cambridge: Cambridge University Press. 512 pp..

HYDE, Susan D. (2015), Experiments in international relations: lab, survey, and field. Annual Review of Political Science. Vol. 18, № 01, pp. 403-424.

INGLEHART, Ronald; HAERPFER, Christian; MORENO, Alejandro; WELZEL, Christian; KIZILOVA, Kseniya; DIEZ-MEDRANO, Jaime; LAGOS, Marta; NORRIS, Pippa; PONARIN, Eduard, and PUNAREN, Bi (eds)(2014), World values survey: round six - country-pooled datafile 2010-2014. Available at $<$ http://www.worldvaluessurvey.org/WVSDocumentationWV6.jsp>. Accessed on March, 31, 2019. 
JOHNS, Robert and DAVIES, Graeme A. M. (2012), Democratic peace or clash of civilizations? Target states and support for war in Britain and the United States. The Journal of Politics. Vol. 74, № 04, pp. 1038-1052.

KANT, Immanuel (1972), Perpetual peace: a philosophical essay. New York: Garland Publishers. 60 pp.

KROENIG, Matthew (2013), Nuclear superiority and the balance of resolve: explaining nuclear crisis outcomes. International Organization. Vol. 67, № 01, pp. 141-171.

LACINA, Bethany and LEE, Charlotte (2013), Culture clash or democratic peace?: Results of a survey experiment on the effect of religious culture and regime type on foreign policy opinion formation. Foreign Policy Analysis. Vol. 09, № 02, pp. 143-170.

LEMKE, Douglas and REED, William (1996), Regime type and status quo evaluations. International Interactions. Vol. 22, № 02, pp. 143-164.

LEVY, Jack S. (1988), Domestic politics and war. Journal of Interdisciplinary History. Vol. 18, № 04, pp. 653-673.

LIPSET, Seymour Martin (1996), American exceptionalism: a double-edged sword. New York: Norton. 352 pp.

LÜ, Xiaobo (2016), Ethical challenges in comparative politics: experiments in China. In: Ethics and experiments: problems and solutions for social scientists and policy professionals. Edited by DESPOSATO, Scott. New York: Routledge. pp. 113-127.

MALHOTRA, Neil and KROSNIK, Jon A. (2007), The effect of survey mode and sampling on inferences about political attitudes and behavior: comparing the 2000 and 2004 ANES to internet surveys with nonprobability samples. Political Analysis. Vol. 15, № 03, pp. 286-323.

MAOZ, Zeev and RUSSETT, Bruce M. (1993), Normative and structural causes of the democratic peace, 1946-1986. American Political Science Review. Vol. 87, № 03 , pp. 624-638.

MESQUITA, Bruce Bueno de and LALMAN, David (1992), War and reason: domestic and international imperatives. New Haven: Yale University Press. 336 pp..

MESQUITA, Bruce Bueno de; MORROW, James D.; SIVERSON, Randolph M., and SMITH, Alastair (1999), An institutional explanation for the democratic peace. American Political Science Review. Vol. 93, № 04, pp. 791-807. 
MINNESOTA POPULATION CENTER (2017), Integrated public use microdata series, international: Version 7.1 [dataset]. Available at $<$ https://international.ipums.org/international/index.shtml>. Accessed on March, 30, 2019.

MINTZ, Alex and GEVA, Nehemia (1993), Why don't democracies fight each other?: An experimental study. Journal of Conflict Resolution. Vol. 37, № 03, pp. 484503.

MOUSSEAU, Michael (2000), Market prosperity, democratic consolidation, and democratic peace. Journal of Conflict Resolution. Vol. 44, № 04, pp. 472-507.

OREN, Ido (1995), The subjectivity of the 'democratic' peace: changing US perceptions of Imperial Germany. International Security. Vol. 20, № 02, pp. 147-184.

OWEN, John M. (1997), Liberal peace, liberal war. Ithaca: Cornell University Press. 246 pp..

PEIFER, Jason and GARRET, Kelly (2014), Best practices for working with opt-in online panels. Available at <https://comm.osu.edu/sites/comm.osu.edu/files/Opt-in_panel_best_practices.pdf>. Accessed on march, 31, 2019.

RIGDON, Joseph and Michael G HUDGENS (2015), Randomization inference for treatment effects on a binary outcome. Statistics in Medicine. Vol. 34, № 06, pp. 924-935.

RISSE-KAPPEN, Thomas (1997), Cooperation among democracies: the European influence on U.S. foreign policy. Princeton: Princeton University Press. 260 pp..

ROSATO, Sebastian (2003), The flawed logic of democratic peace theory. American Political Science Review. Vol. 97, № 04, pp. 585-602.

ROUSSEAU, David L.; GELPI, Christopher; REITER, Dan, and HUTH, Paul K. (1996), Assessing the dyadic nature of the democratic peace, 1918-1988. American Political Science Review. Vol. 90, № 03, pp. 512-533.

RUSSETT, Bruce (1993), Grasping the democratic peace: principles for a post-cold war world. Princeton: Princeton University Press. 184 pp..

RUSSETT, Bruce and ONEAL, John R. (2001), Triangulating peace: democracy, interdependence, and international organizations. New York: Norton. 393 pp..

SAGAN, Scott D. and WALTZ, Kenneth N. (2012), The spread of nuclear weapons: an enduring debate. New York: W.W. Norton \& Company. 288 pp.. 
SCHULTZ, Kenneth A. (1999), Do domestic institutions constrain or inform?: Contrasting two institutional perspectives on democracy and war. International Organization. Vol. 53, № 02, pp. 233-266.

SCHULTZ, Kenneth A. (1998), Domestic opposition and signaling in international crises. American Political Science Review. Vol. 94, № 04, pp. 829-844.

SECHSER, Todd S. and FUHRMANN, Matthew (2013), Crisis bargaining and nuclear blackmail. International Organization. Vol. 67, № 01, pp. 173-195.

SLANTCHEV, Branislav L. (2012), Audience cost theory and its audiences. Security Studies. Vol. 21, № 03, pp. 376-382.

SMALL, Melvin (1996), Democracy and diplomacy: the impact of domestic politics on U.S. foreign policy, 1789-1994. Baltimore: Johns Hopkins University Press. 200 pp..

SMALL, Melvin and SINGER, J. David (1976), The war proneness of democratic regimes, 1816-1965. The Jerusalem Journal of International Relations. Vol. 01, № 04 , pp. 50-69.

SMITH, Alastair (1998), International crises and domestic politics. American Political Science Review. Vol. 92, № 03, pp. 623-638.

SPIRO, David E. (1994), The insignificance of the liberal peace. International Security. Vol. 19, № 02, pp. 50-86.

THOMPSON, Alexander (2006), Coercion through IOs: the security council and the logic of information transition. International Organization. Vol. 60, № 01, pp. 01-34.

TINGLEY, Dustin and TOMZ, Michael (2012), How does the UN security council influence public opinion? Available at <https://web.stanford.edu/ tomz/working/TingleyTomz-UNSC-2012-11-04.pdf>. Accessed on November, 06, 2019.

TOMZ, Michael and WEEKS Jessica (2018), Human rights, democracy, and international conflict. Available at <http://kingcenter.stanford.edu/sites/ default/files/publications/WP1026.pdf>. Accessed on November, 06, 2019.

TOMZ, Michael and WEEKS Jessica (2013), Public opinion and the democratic peace. American Political Science Review. Vol. 107, № 04, pp. 849-865.

VAN BELLE, Douglas A. (1997), Press freedom and the democratic peace. Journal of Peace Research. Vol. 34, № 04, pp. 405-414. 
VOETEN, Erik (2005), The political origins of the UN Security Council's ability to legitimize the use of force. International Organization. Vol. 59, № 03, pp. 527557.

WARD, Michael D. and GLEDITSCH, Kristian S. (1998), Democratizing for peace. American Political Science Review. Vol. 92, № 01, pp. 51-61.

WEART, Spencer R. (1998), Never at war: why democracies will not fight one another. New Haven: Yale University Press. 432 pp..

WENDT, Alexander (1999), Social theory of international politics. Cambridge: Cambridge University Press. 429 pp.. 


\section{Appendix}

Table S05. Detailed recruitment statistics

\begin{tabular}{lll} 
& Brazil & China (Sample 01) \\
\cline { 2 - 3 } Field dates & $08 / 21 / 2013-$ & $08 / 22 / 2013-09 / 12 / 2013$ \\
Number of invitations to take the survey & $09 / 17 / 2013$ & \\
Consented to take the survey (raw N) & 4,480 & 38,568 \\
Eliminated due to age & 08 & 5,797 \\
Eliminated due to repeat responses & 0 & 08 \\
Complete entries & 3,282 & 0 \\
Partial entries & 932 & 5,431 \\
Overall N (complete/partial entries) & 4,214 & 313 \\
Median completion time (min) & 06 & 5,744
\end{tabular}

Source: Prepared by the authors with their own data.

Note: Overall $\mathrm{N}$ is the sum of complete and partially complete entries. Our survey included a feature to prevent respondents from taking the survey multiple times by placing a cookie on their browser. Some respondents had the same IP addresses, presumably sharing the device on which they took the survey, as in the case of members of the same household participating in the survey. We wanted to allow this possibility and drop only those respondents who got the same treatments and produced same responses repeatedly from one IP address.

For Sample 02, YouGov created a sampling frame representative of Internet Users in China based on gender, age, educational attainment, and income using the annual report by the China Internet Network Information Center (2014). YouGov then recruited a total of 2,723 respondents and matched those respondents to a sampling target of 2,500 based on gender, age, and income.

Table S06. Summary statistics (Brazil Sample)

\begin{tabular}{llllllll}
\hline Statistic & $\mathrm{N}$ & Mean & St. Dev. & Min & $\begin{array}{l}\text { Pctl } \\
(25)\end{array}$ & $\begin{array}{l}\text { Pctl } \\
(75)\end{array}$ & Max \\
\hline CoW Country Code & 4,214 & 140.000 & 0.000 & 140 & 140 & 140 & 140 \\
Support for Attack & 4,212 & 0.359 & 0.480 & 0.000 & 0.000 & 1.000 & 1.000 \\
Vignette & 4,214 & 2.494 & 1.110 & 01 & 02 & 03 & 04 \\
Democracy & 4,214 & 0.501 & 0.500 & 0 & 0 & 01 & 01 \\
Treatment & & & & & & & \\
UN Treatment & 4,214 & 0.504 & 0.500 & 0 & 0 & 01 & 01 \\
Militarism & 4,181 & 0.258 & 0.302 & 0.000 & 0.000 & 0.500 & 1.000 \\
Internationalism & 4,166 & 0.599 & 0.176 & 0.000 & 0.500 & 0.750 & 1.000 \\
Nationalism & 4,182 & 0.411 & 0.228 & 0.000 & 0.250 & 0.500 & 1.000 \\
Specific Case & 4,165 & 0.260 & 0.439 & 0.000 & 0.000 & 1.000 & 1.000 \\
Age & 4,214 & 36.112 & 12.564 & 18 & 25 & 46 & 79 \\
Female & 4,190 & 0.519 & 0.500 & 0.000 & 0.000 & 1.000 & 1.000 \\
Education & 4,204 & 4.387 & 1.373 & 1.000 & 3.000 & 5.000 & 7.000 \\
Income & 3,753 & 3.890 & 1.146 & 1.000 & 3.000 & 5.000 & 5.000 \\
Read International & 4,203 & 4.059 & 2.548 & 0.000 & 2.000 & 7.000 & 7.000 \\
News (Days Per & & & & & & & \\
Week) & & & & & & & \\
Is Religious & 3,955 & 0.856 & 0.351 & 0.000 & 1.000 & 1.000 & 1.000 \\
Religiosity & 3,954 & 0.338 & 0.352 & 0.000 & 0.000 & 0.500 & 1.000 \\
\hline
\end{tabular}

Source: Prepared by the authors with their own data. 
Table S07. Summary statistics (China Sample 01)

\begin{tabular}{llllllll}
\hline Statistic & N & Mean & St. Dev. & Min & $\begin{array}{l}\text { Pctl } \\
(25)\end{array}$ & $\begin{array}{l}\text { Pctl } \\
(75)\end{array}$ & Max \\
\hline CoW Country Code & 5,744 & 710.000 & 0.000 & 710 & 710 & 710 & 710 \\
Support for Attack & 5,743 & 0.515 & 0.500 & 0.000 & 0.000 & 1.000 & 1.000 \\
Vignette & 5,744 & 2.530 & 1.121 & 01 & 02 & 04 & 04 \\
Democracy Treatment & 5,744 & 0.486 & 0.500 & 0 & 0 & 01 & 01 \\
UN Treatment & 5,744 & 0.497 & 0.500 & 0 & 0 & 01 & 01 \\
Militarism & 5,662 & 0.511 & 0.403 & 0.000 & 0.000 & 1.000 & 1.000 \\
Internationalism & 5,682 & 0.719 & 0.129 & 0.125 & 0.625 & 0.812 & 1.000 \\
Nationalism & 5,680 & 0.744 & 0.165 & 0.000 & 0.625 & 0.875 & 1.000 \\
Specific Case & 5,730 & 0.281 & 0.449 & 0.000 & 0.000 & 1.000 & 1.000 \\
Age & 5,744 & 31.375 & 8.331 & 18 & 25 & 36 & 82 \\
Female & 5,696 & 0.435 & 0.496 & 0.000 & 0.000 & 1.000 & 1.000 \\
Education & 5,725 & 4.758 & 0.984 & 1.000 & 5.000 & 5.000 & 7.000 \\
Income & 5,723 & 3.788 & 1.027 & 1.000 & 3.000 & 5.000 & 5.000 \\
Read International & 5,731 & 4.552 & 2.319 & 0.000 & 3.000 & 7.000 & 7.000 \\
News (Days Per Week) & & & & & & & \\
Is Religious & 5,732 & 0.433 & 0.496 & 0.000 & 0.000 & 1.000 & 1.000 \\
Religiosity & 5,720 & 0.098 & 0.215 & 0.000 & 0.000 & 0.000 & 1.000
\end{tabular}

Source: Prepared by the authors with their own data.

Table S08. Summary statistics (China Sample 02)

\begin{tabular}{llllllll}
\hline Statistic & $\mathrm{N}$ & Mean & St. Dev. & Min & $\begin{array}{l}\text { Pctl } \\
(25)\end{array}$ & $\begin{array}{l}\text { Pctl } \\
(75)\end{array}$ & Max \\
\hline CoW Country Code & 2,500 & 710.000 & 0.000 & 710 & 710 & 710 & 710 \\
Support for Attack & 2,496 & 0.524 & 0.500 & 0.000 & 0.000 & 1.000 & 1.000 \\
Vignette & 2,500 & 2.518 & 1.121 & 01 & 02 & 04 & 04 \\
Democracy Treatment & 2,500 & 0.492 & 0.500 & 0 & 0 & 01 & 01 \\
UN Treatment & 2,500 & 0.498 & 0.500 & 0 & 0 & 01 & 01 \\
Militarism & 2,401 & 0.460 & 0.405 & 0.000 & 0.000 & 1.000 & 1.000 \\
Internationalism & 2,456 & 0.698 & 0.132 & 0.000 & 0.625 & 0.750 & 1.000 \\
Nationalism & 2,477 & 0.735 & 0.174 & 0.000 & 0.625 & 0.875 & 1.000 \\
Specific Case & 2,491 & 0.261 & 0.439 & 0.000 & 0.000 & 1.000 & 1.000 \\
Age & 2,500 & 32.288 & 10.913 & 18 & 24 & 39 & 82 \\
Female & 2,500 & 0.424 & 0.494 & 0 & 0 & 01 & 01 \\
Education & 2,500 & 4.123 & 1.239 & 01 & 03 & 05 & 07 \\
Income & 2,500 & 2.072 & 1.081 & 01 & 01 & 02 & 05 \\
Read International News & 2,489 & 3.472 & 2.572 & 0.000 & 1.000 & 7.000 & 7.000 \\
(Days Per Week) & & & & & & & \\
Is Religious & 2,489 & 0.448 & 0.497 & 0.000 & 0.000 & 1.000 & 1.000 \\
Religiosity & 2,480 & 0.088 & 0.216 & 0.000 & 0.000 & 0.000 & 1.000 \\
\hline
\end{tabular}

Source:Prepared by the authors with their own data. 
Table S09. Top ten countries/regions mentioned by non-complying respondents

\begin{tabular}{|c|c|c|c|c|c|c|}
\hline & Brazil & & & & na & \\
\hline & Country/Region & $\mathrm{N}$ & $\begin{array}{l}\text { Sample } 01 \\
\text { Country/Region }\end{array}$ & $\mathrm{N}$ & $\begin{array}{l}\text { Sample } 02 \\
\text { Country/Region }\end{array}$ & $\mathrm{N}$ \\
\hline 01 & Syria & $\begin{array}{l}213 \\
(18.816 \%)\end{array}$ & North Korea & $\begin{array}{l}725 \\
(44.697 \%)\end{array}$ & Japan & $\begin{array}{l}417 \\
(63.373 \%)\end{array}$ \\
\hline 02 & Iran & $\begin{array}{l}151 \\
(13.339 \%)\end{array}$ & Japan & $\begin{array}{l}292 \\
(18.002 \%)\end{array}$ & North Korea & $\begin{array}{l}63 \\
(9.574 \%)\end{array}$ \\
\hline 03 & North Korea & $\begin{array}{l}151 \\
(13.339 \%)\end{array}$ & US & $\begin{array}{l}258 \\
(15.906 \%)\end{array}$ & US & $\begin{array}{l}47 \\
(7.142 \%)\end{array}$ \\
\hline 04 & US & $\begin{array}{l}150 \\
(13.250 \%)\end{array}$ & Syria & $\begin{array}{l}84 \\
(5.178 \%)\end{array}$ & China & $\begin{array}{l}41 \\
(6.231 \%)\end{array}$ \\
\hline 05 & Korea & $\begin{array}{l}45 \\
(3.975 \%)\end{array}$ & Iran & $\begin{array}{l}68 \\
(4.192 \%)\end{array}$ & Iran & $\begin{array}{l}07 \\
(1.063 \%)\end{array}$ \\
\hline 06 & Brazil & $\begin{array}{l}34 \\
(3.003 \%)\end{array}$ & China & $\begin{array}{l}40 \\
(2.466 \%)\end{array}$ & Russia & $\begin{array}{l}05 \\
(0.759 \%)\end{array}$ \\
\hline 07 & Iraq & $\begin{array}{l}25 \\
(2.208 \%)\end{array}$ & South Korea & $\begin{array}{l}30 \\
(1.849 \%)\end{array}$ & The Philippines & $\begin{array}{l}05 \\
(0.759 \%)\end{array}$ \\
\hline 08 & South Korea & $\begin{array}{l}22 \\
(1.943 \%)\end{array}$ & India & $\begin{array}{l}12 \\
(0.739 \%)\end{array}$ & Canada & $\begin{array}{l}03 \\
(0.455 \%)\end{array}$ \\
\hline 09 & Middle East & $\begin{array}{l}18 \\
(1.590 \%)\end{array}$ & Iraq & $\begin{array}{l}11 \\
(0.678 \%)\end{array}$ & France & $\begin{array}{l}02 \\
(0.303 \%)\end{array}$ \\
\hline 10 & China & $\begin{array}{l}16 \\
(1.413 \%)\end{array}$ & Russia & $\begin{array}{l}4 \\
(0.246 \%)\end{array}$ & UK & $\begin{array}{l}02 \\
(0.303 \%)\end{array}$ \\
\hline $\begin{array}{l}\text { Tot: } \\
\text { com }\end{array}$ & $\begin{array}{l}\text { N of Non- } \\
\text { liers }\end{array}$ & 1,132 & & 1,622 & & 658 \\
\hline Tot: & N of Compliers & 3,131 & & 4,136 & & 1,851 \\
\hline
\end{tabular}

Source: Prepared by the authors with their own data.

Note: The table lists the ten countries mostly frequently listed by non-complying respondents who admit- ted they were thinking of a specific country, rather than a generic one, defying our instruction to think of the latter in the beginning. These non-compliers were asked to list the specific countries in at the end of the survey. We did not explicitly state a limit to the number of countries they can list and respondents were free to list as many countries as they can fit into the blank. Here we show only the first country they listed in their open-ended response, analyzing only one observation per respondent. 
Table S10. Support for an attack and the effect of democracy, controlling for attitudinal and demographic attributes

$$
\text { Brazil }
$$

China (Sample 1)

\begin{tabular}{|c|c|c|c|c|c|c|c|c|c|c|}
\hline & \multirow{3}{*}{$\begin{array}{c}\text { \% Support for } \\
\text { Attacking } \\
\text { a Democracy }\end{array}$} & \multirow{3}{*}{$\mathrm{N}$} & \multirow{3}{*}{$\begin{array}{c}\text { \% Support for } \\
\text { Attacking } \\
\text { an Autocracy }\end{array}$} & \multirow{3}{*}{$\mathrm{N}$} & \multirow{2}{*}{\multicolumn{2}{|c|}{$\begin{array}{c}\text { Effect of \% Support for } \\
\text { Attacking }\end{array}$}} & \multirow{3}{*}{$\mathrm{N}$} & \multicolumn{3}{|c|}{ \% Support for Attacking } \\
\hline & & & & & & & & & $\mathrm{N}$ & \\
\hline & & & & & Democracy & a Democracy & & an Autocracy & & Effect of Democracy \\
\hline \multicolumn{11}{|c|}{ Militarism } \\
\hline Weak & 24.543 & 1,149 & 31.025 & 1,112 & $-6.482 \leftarrow \leftarrow \leftarrow$ & 30.342 & 847 & 32.147 & 927 & -1.804 \\
\hline Medium & 37.173 & 842 & 46.707 & 835 & $-9.533 \leftarrow \kappa k$ & 46.458 & 960 & 51.748 & 1,030 & $-5.289 \kappa \kappa$ \\
\hline Strong & 73.585 & 106 & 72.059 & 136 & 1.526 & 71.789 & 950 & 74.446 & 947 & -2.656 \\
\hline \multicolumn{11}{|c|}{ Internationalism } \\
\hline Weak & 27.368 & 95 & 32.990 & 97 & -5.621 & 83.333 & 6 & 80.000 & 5 & 3.333 \\
\hline Medium & 30.860 & 1,442 & 38.184 & 1,388 & $-7.325 \leftarrow \leftarrow \leftarrow$ & 53.198 & 1,376 & 55.866 & 1,432 & -2.668 \\
\hline Strong & 36.479 & 551 & 45.178 & 591 & $-8.699 \kappa \kappa \leftarrow$ & 46.647 & 1,387 & 49.627 & 1,475 & -2.980 \\
\hline \multicolumn{11}{|c|}{ Nationalism } \\
\hline Weak & 31.385 & 787 & 38.996 & 777 & $-7.611 \leftarrow \leftarrow \leftarrow$ & 41.667 & 24 & 68.000 & 25 & $-26.333 \kappa$ \\
\hline Medium & 30.556 & 1,044 & 39.089 & 1,054 & $-8.534 k-k \leftarrow$ & 45.358 & 851 & 47.948 & 999 & -2.590 \\
\hline Strong & 39.777 & 269 & 46.586 & 249 & -6.809 & 52.331 & 1,888 & 55.444 & 1,892 & $-3.113 \kappa$ \\
\hline \multicolumn{11}{|c|}{ Manipulation Check } \\
\hline Generic Case & 31.052 & 1,549 & 38.316 & 1,532 & $-7.264 \kappa \leftarrow \leftarrow$ & 48.044 & 2,019 & 51.284 & 2,102 & $-3.241 \leftarrow \kappa$ \\
\hline Specific Case & 35.460 & 533 & 44.627 & 549 & $-9.167 k \leftarrow \leftarrow$ & 55.642 & 771 & 56.870 & 837 & -1.228 \\
\hline Female & 28.105 & 1,103 & 34.641 & 1,071 & $-6.535 \leftarrow \leftarrow \leftarrow$ & 47.966 & 1,180 & 50.463 & 1,296 & -2.497 \\
\hline Male & 36.710 & 997 & 45.329 & 1,017 & $-8.619 \kappa \kappa \kappa$ & 51.387 & 1,586 & 54.685 & 1,633 & $-3.297 \leftarrow$ \\
\hline \multicolumn{11}{|c|}{ Education } \\
\hline Less than High School Diploma & 33.333 & 90 & 45.000 & 80 & -11.667 & 54.237 & 59 & 50 & 72 & 4.237 \\
\hline High School Diploma & 33.031 & 551 & 39.771 & 523 & $-6.740 \kappa \kappa$ & 52.294 & 327 & 54.913 & 346 & -2.620 \\
\hline Some College or College Degree & 31.943 & 1,127 & 39.697 & 1,121 & $-7.753 \leftarrow \leftarrow \leftarrow$ & 50.068 & 2,221 & 53.189 & 2,305 & $-3.121 \kappa \kappa$ \\
\hline $\begin{array}{l}\text { Some Graduate School or Graduate } \\
\text { Degree }\end{array}$ & 30.861 & 337 & 39.142 & 373 & $-8.282 \kappa \kappa$ & 46.023 & 176 & 46.330 & 218 & -0.308 \\
\hline \multicolumn{11}{|c|}{ Income } \\
\hline 1st and 2nd Income Quintiles & 33.113 & 302 & 38.356 & 292 & -5.244 & 50.974 & 308 & 53.151 & 365 & -2.177 \\
\hline 3rd Income Quintile & 29.651 & 344 & 40.312 & 320 & $-10.661 \leftarrow \kappa k$ & 47.331 & 712 & 54.051 & 790 & $-6.719 \leftarrow \kappa k$ \\
\hline 4th Income Quintile & 33.261 & 460 & 37.427 & 513 & -4.166 & 51.844 & 922 & 52.741 & 912 & -0.897 \\
\hline 5th Income Quintile & 33.207 & 789 & 42.955 & 731 & $-9.748 \leftarrow \leftarrow \leftarrow$ & 50.000 & 840 & 52.005 & 873 & -2.005 \\
\hline
\end{tabular}




\begin{tabular}{|c|c|c|c|c|c|c|c|c|c|c|}
\hline \multicolumn{11}{|c|}{ International News } \\
\hline Read Int'l News 0-2 Days/Week & 32.349 & 711 & 35.972 & 720 & -3.623 & 48.632 & 658 & 54.306 & 720 & $-5.673 \kappa \kappa$ \\
\hline Read Int'l News 3-5 Days/Week & 31.448 & 601 & 39.932 & 591 & $-8.485 \leftarrow \kappa \kappa$ & 51.875 & 960 & 53.854 & 1,025 & -1.979 \\
\hline$\underline{\text { Read Int'l News Everyday }}$ & 32.197 & 792 & 43.384 & 786 & $-11.187 \leftarrow \kappa \kappa$ & 49.360 & 1,171 & 51.421 & 1,196 & -2.062 \\
\hline \multicolumn{11}{|c|}{ Religion } \\
\hline Religious & 32.572 & 1,707 & 40.573 & 1,676 & $-8.001 \leftarrow \leftarrow \leftarrow$ & 50.161 & 1,242 & 51.290 & 1,240 & -1.129 \\
\hline No Religion & 32.331 & 266 & 35.855 & 304 & -3.524 & 50.000 & 1,546 & 53.905 & 1,703 & $-3.905 \kappa \kappa$ \\
\hline \multicolumn{11}{|c|}{ Religiosity } \\
\hline Weak & 33.933 & 834 & 40.247 & 810 & $-6.314 \leftarrow \leftarrow \leftarrow$ & 49.071 & 2154 & 53.489 & 2,307 & $-4.418 \leftarrow \kappa k$ \\
\hline Medium & 32.551 & 682 & 40.565 & 673 & $-8.013 \leftarrow \leftarrow \leftarrow$ & 53.346 & 523 & 50.000 & 484 & 3.346 \\
\hline Strong & 28.821 & 458 & 39.394 & 495 & $-10.573 \leftarrow \leftarrow \leftarrow$ & 52.381 & 105 & 52.740 & 146 & -0.359 \\
\hline
\end{tabular}

Source: Prepared by the authors with their own data.

Note: The table displays the percentage of respondents who supported military action against a non-democratic target and the effect of democracy, controlling for attitudinal and demographic variables. The difference in the percentages is estimated as the effect of democracy. Asterisks $\left(* * * \mathrm{p}<0.01,{ }^{* *} \mathrm{p}<0.05,{ }^{*} \mathrm{p}<0.1\right)$ show the statistical significance of the effect. 